\title{
DISTRIBUTION OF IMMUNOREACTIVE $\beta$-NEO-ENDORPHIN IN DISCRETE AREAS OF THE RAT BRAIN AND PITUITARY GLAND: COMPARISON WITH $\alpha$-NEO-ENDORPHIN
}

\author{
NADAV ZAMIR, ${ }^{1}$ MIKLOS PALKOVITS, AND MICHAEL J. BROWNSTEIN \\ Laboratory of Cell Biology, National Institute of Mental Health, Bethesda, Maryland 20205
}

Received August 5, 1983; Revised December 2, 1983; Accepted December 2, 1983

\begin{abstract}
The distribution of immunoreactive (ir)- $\beta$-neo-endorphin in 101 miscrodissected rat brain and spinal cord regions as well as in the neurointermediate lobe of pituitary gland was determined using a highly specific radioimmunoassay. The highest concentration of $\beta$-neo-endorphin in brain was found in the median eminence $(341.4 \mathrm{fmol} / \mathrm{mg}$ of protein). High concentrations of ir- $\beta$-neoendorphin $(>250 \mathrm{fmol} / \mathrm{mg}$ of protein) were found in 11 nuclei, including dorsomedial nucleus, substantia nigra, parabrachial nuclei, periaqueductal gray matter, anterior hypothalamic nucleus, and lateral preoptic areas. Moderate concentrations of the peptide (between 100 and $250 \mathrm{fmol} / \mathrm{mg}$ of protein) were found in 66 brain nuclei such as the amygdaloid and septal nuclei, most of the diencephalic structures (not including the hypothalamus), and the majority of the medulla oblongata nuclei and others. Low concentrations of ir- $\beta$-neo-endorphin $(<100 \mathrm{fmol} / \mathrm{mg}$ of protein) were found in 21 nuclei, e.g., cortical structures (frontal., cingulate, piriform, parietal, entorhinal, occipital), olfactory tubercle, and cerebellum (nuclei and cortex). The olfactory bulb has the lowest $\beta$-neoendorphin concentration $(21.3 \mathrm{fmol} / \mathrm{mg}$ of protein). Spinal cord segments exhibit low peptide concentrations. The neurointermediate lobe of the pituitary gland is extremely rich in ir- $\beta$-neoendorphin.
\end{abstract}

$\beta$-Neo-endorphin is an endogenous opioid peptide which was originally isolated from extracts of porcine hypothalami (Minamino et al., 1981). It is a potent opiate agonist in the in vitro guinea pig ileum assay (Minamino et al., 1981; Oka et al., 1982). $\beta$-Neo-endorphin is identical to $\alpha$-neo-endorphin except that it lacks a lysine residue at the carboxyl terminal (Kangawa et al., 1981, Minamino et al., 1981). The structural relationship of the two peptides is illustrated below:

$\alpha$-neo-endorphin: Tyr-Gly-Gly-Phe-Leu-Arg-Lys-Tyr-Pro-Lys

$\beta$-neo-endorphin: Tyr-Gly-Gly-Phe-Leu-Arg-Lys-Tyr-Pro

$\alpha$ - and $\beta$-Neo-endorphin are parts of the same precursor that gives rise to dynorphin A (Goldstein et al., 1981) and dynorphin B (Fischli et al., 1982; Kilpatrick et al., 1982). The amino acid sequence of this precursor has been deduced from the nucleotide sequence of cloned DNA complementary to the porcine hypothalamic mRNA encoding it (Kakidani et al., 1982). Immunohistochemical studies have shown that perikarya, nerve fibers, and terminals containing $\alpha$-neo-endorphin are widely distributed throughout the central nervous system (Weber et al., 1982a). The distribution of $\beta$-neo-endor-

\footnotetext{
${ }^{1}$ To whom correspondence should be addressed.
}

phin measured by radioimmunoassay (RIA) in gross brain areas has been reported (Kitamura et al., 1982). The hypothalamus is the region richest in the peptide, followed by the pons-medulla, midbrain, spinal cord, cortex, hippocampus, and striatum. The cerebellum and olfactory bulb contain relatively little $\beta$-neo-endorphin. The posterior pituitary has a high $\beta$-neo-endorphin concentration (Weber et al., 1982a, b). In this paper we describe the topographical distribution of ir- $\beta$-neo-endorphin among 101 microdissected brain and spinal cord areas as well as the neurointermediate lobe of the pituitary gland.

\section{Materials and Methods}

Animals. Male Sprague-Dawley rats (Zivic Miller Laboratories, Inc., Allison Park, PA), weighing 220 to 250 $\mathrm{gm}$, were housed under alternate 12 -hour periods of dark and light (lights on from 6:00 A.M. to 6:00 P.M.) and were given standard rat chow and tap water ad libitum.

Tissue preparation and extraction. The animals were killed by decapitation between 8:00 and 10:00 A.M. The brains and spinal cords were quickly removed and frozen on dry ice. The spinal cords were grossly dissected into cervical, thoracic, and lumbar segments. Brain nuclei 
were removed by the micropunch method (Palkovits, 1973) from 300- $\mu$ m-thick coronal frozen sections cut in a cryostat at $-10^{\circ} \mathrm{C}$. Tissue from each microdissected area was pooled from two animals. $\beta$-Neo-endorphin and $\alpha$-neo-endorphin were assayed in the same tissue samples. (The distribution of the latter has been presented in the preceding report by Zamir et al., 1984). The pituitary gland was immediately removed and dissected into neurointermediate and anterior lobes.

Tissue samples were placed in 1.5-ml conical Eppendorf tubes containing $200 \mu \mathrm{l}$ of $0.1 \mathrm{~N} \mathrm{HCl}$ and transferred to a boiling water bath for $10 \mathrm{~min}$. The tissue samples were then homogenized by sonication, and $20-\mu \mathrm{l}$ aliquots of the homogenates were removed for protein determination (Lowry et al., 1951). The extracts were centrifuged at $2000 \times g$ for $10 \mathrm{~min}$ at $4^{\circ} \mathrm{C}$. The supernatants were transferred to $12 \times 75 \mathrm{~mm}$ polypropylene tubes and evaporated to dryness in a vacuum centrifuge. 'I'he efficiency of the extraction was determined to be 80 to $90 \%$ by measuring the recovery of $\left[{ }^{125} \mathrm{I}\right]-\beta$-neo-endorphin internal standards from tissue homogenates.

To determine whether conversion of $\alpha$-nen-endorphin to $\beta$-neo-endorphin occurs in the course of tissue preparation, we measured the concentrations of these peptides in samples of median eminence, supraoptic nucleus, and paraventricular nucleus dissected from frozen slices and slices of unfrozen brain cut with a razor blade. Neither the concentrations nor the ratio of $\alpha$-neo-endorphin to $\beta$-neo-endorphin changed detectably due to the one brief freeze-thaw cycle required for mounting frozen sections in the microdissection technique used.

Radioimmunoassay (RIA). Samples were rehydrated in phosphate-buffered saline ( $\mathrm{pH} 7.6$ ) containing $0.1 \%$ gelatin, $0.1 \%$ bovine serum albumin, $0.1 \%$ Triton $\mathrm{X}-100$, and $0.01 \%$ merthiolate. The antiserum was used at final dilution of $1: 10,000$ at which dilution 30 to $40 \%$ of the ${ }^{125}$ I-labeled $\beta$-neo-endorphin was bound. Each sample was incubated at $4^{\circ} \mathrm{C}$ in a $500-\mu \mathrm{l}$ volume that contained $300 \mu \mathrm{l}$ of sample in assay buffer, $100 \mu \mathrm{l}$ of ${ }^{125}$ I-labeled $\beta$ neo-endorphin, and $100 \mu \mathrm{l}$ of $\beta$-neo-endorphin antiserum in assay butfer. After 16 to $24 \mathrm{hr}, 1 \mathrm{ml}$ of dextran-coated charcoal in phosphate-buffered saline (2.5 gm of charcoal and $0.25 \mathrm{gm}$ of dextran/liter) was added to each tube, and the tubes were incubated at $4^{\circ} \mathrm{C}$ for $10 \mathrm{~min}$ and centrifuged at $2000 \times g$ for $20 \mathrm{~min}$. The radioactivity of the supernatant was measured in a Micromedic 4/200 gamma counter. The RIA sensitivity (i.e., the amount of peptide that displaced $20 \%$ of the label) was 8 to $10 \mathrm{pg}$.

Properties of the antiserum. The antiserum was a gift from E. Weber (Stanford University, Palo Alto, CA). The specificity of the $\beta$-neo-endorphin antiserum has been described (Weber et al., 1982a). The antiserum shows less than $0.01 \%$ cross-reactivity with a $\alpha$-neoendorphin. It does not cross-react with Leu-enkephalin, Met-enkephalin, dynorphin A, or dynorphin A(1-8).

Peptides. $\beta$-Neo-endorphin was purchased from Peninsula Laboratories (San Carlos, CA).

Iodination procedure. Synthetic $\beta$-neo-endorphin was iodinated with $\mathrm{Na}^{125} \mathrm{I}$, using chloramine $\mathrm{T}$ (Hunter et al., 1962). The reaction was stopped with sodium metabisulfite. The radiolabeled peptide was purified by chromatography on octadecylsilyl-silica cartridges (ODS silica,
Sep-Pak $\mathrm{C}_{18}$, Waters Associates), using an increasing gradient of methanol in $0.01 \mathrm{M} \mathrm{HCl} / 0.1 \mathrm{M}$ acetic acid solution.

\section{Results}

ir- $\beta$-Neo-endorphin was detectable in all brain and spinal cord areas investigated. The peptide is unevenly distributed. A 16.0-fold difference in $\beta$-neo-endorphin concentration was measured between the richest (median eminence, $341.4 \mathrm{fmol} / \mathrm{mg}$ of protein) and the poorest (olfactory bulb, $21.3 \mathrm{fmol} / \mathrm{mg}$ of protein) brain regions. The spinal cord contains low levels of the peptide, whereas the neurointermediate lobe is extremely rich in it $(9407.3 \mathrm{fmol} / \mathrm{mg}$ of protein).

Telencephalon (Table I). The telencephalic structures contain low to moderate concentrations of $\beta$-neo-endorphin. The cerebral cortical areas contain low levels of the peptide $(<100 \mathrm{fmol} / \mathrm{mg}$ of protein); limbic system structures (hippocampus, dentate gyrus, amygdaloid nuclei, and septal nuclei) have moderate levels (between 100 and $250 \mathrm{fmol} / \mathrm{mg}$ of protein). The central and lateral amygdaloid nuclei have higher $\beta$-neo-endorphin concentrations than the other telencephalic structures (205.9 and $226.1 \mathrm{fmol} / \mathrm{mg}$ of protein, respectively). The basal ganglia (rostral component of extrapyramidal system) contain moderate (nucleus accumbens, globus pallidus, and claustrum) to low (caudate and caudate-putamen) levels of the peptide.

Diencephalon (not including the hypothalamus) (Table

TABLE I

ir- $\beta$-Neo-endorphin concentrations in telencephalic nuclei of the rat

\begin{tabular}{|c|c|c|c|}
\hline & Regions & $\begin{array}{l}\text { ir- } \beta \text {-Neo-endorphin } \\
\text { Concentrations } \\
\text { (mean } \pm \text { SEM) }\end{array}$ & $\begin{array}{l}\text { Molar Ratio } \\
(\alpha \text {-neo: } \beta \text {-neo })\end{array}$ \\
\hline & & fmul/mus of protein & \\
\hline 1 & Frontal cortex & $72.2 \pm 4.6(5)^{b}$ & 0.8 \\
\hline 2 & Cingulate cortex & $64.5 \pm 14.8(6)$ & 0.9 \\
\hline 3 & Piriform cortex & $87.8 \pm 15.4(5)$ & 1.1 \\
\hline 4 & Parietal cortex & $65.5 \pm 7.1(5)$ & 0.9 \\
\hline 5 & Entorhinal cortex & $96.2 \pm 22.9(6)$ & 1.2 \\
\hline 6 & Occipital cortex & $71.7 \pm 14.5(6)$ & 1.4 \\
\hline 7 & Claustrum & $113.1 \pm 22.6(6)$ & 0.8 \\
\hline 8 & Hippocampus & $110.4 \pm 17.2(6)$ & 3.7 \\
\hline 9 & Dentate gyrus & $126.2 \pm 26.6(6)$ & 5.4 \\
\hline 10 & Olfactory bulb & $21.3 \pm 3.5(6)$ & 2.0 \\
\hline 11 & Olfactory tubercle & $95.0 \pm 14.0(5)$ & 1.9 \\
\hline 12 & Nucleus of the diagonal band & $129.8 \pm 18.2(6)$ & 2.6 \\
\hline 13 & Nucleus accumbens & $124.7 \pm 23.2(6)$ & 5.1 \\
\hline 14 & $\begin{array}{l}\text { Bed nucleus of the stria } \\
\text { terminalis }\end{array}$ & $160.5 \pm 25.5(6)$ & 2.8 \\
\hline 15 & Globus pallidus & $104.7 \pm 12.8(6)$ & 6.0 \\
\hline 16 & Caudate nucleus & $67.0 \pm 7.8(5)$ & 2.6 \\
\hline 17 & Caudate-putamen & $70.4 \pm 12.3(6)$ & 3.4 \\
\hline 18 & Lateral septal nucleus & $138.9 \pm 35.9(6)$ & 2.1 \\
\hline 19 & Medial septal nucleus & $115.1 \pm 14.9(5)$ & 1.2 \\
\hline 20 & Dorsal septal nucleus & $101.9 \pm 22.0(5)$ & 1.4 \\
\hline 21 & Cortical amygdaloid nucleus & $146.8 \pm 32.8(5)$ & 0.7 \\
\hline 22 & Basal amygdaloid nucleus & $171.7 \pm 34.9(6)$ & 0.8 \\
\hline 23 & Medial amygdaloid nucleus & $179.4 \pm 40.8(6)$ & 1.0 \\
\hline 24 & Lateral amygdaloid nucleus & $205.9 \pm 31.8(6)$ & 0.7 \\
\hline 25 & Central amygdaloid nucleus & $226.1 \pm 28.9(6)$ & 1.9 \\
\hline
\end{tabular}

${ }^{a}$ Rased on Zamir et. al., 1984.

${ }^{b}$ Numbers in parentheses, number of samples. 
II). The thalamic (with the exception of the ventral thalamic nucleus, which is poor in peptide), epithalamic (habenula), metathalamic (geniculates), and subthalamic (zona incerta) structures all contain moderate levels of $\beta$-neo-endorphin. The nucleus reuniens is the richest thalamic nucleus $(171.6 \mathrm{fmol} / \mathrm{mg}$ of protein).

Hypothalamus. In general the hypothalamic nuclei are relatively rich in ir- $\beta$-neo-endorphin (Table III). The median eminence contains the highest $\beta$-neo-endorphin concentration in the brain (341.1 fmol/mg of protein). High levels of the peptide (above $250 \mathrm{fmol} / \mathrm{mg}$ of protein) were measured in the dorsomedial, anterior hypothalamic, arcuate, paraventricular, ventromedial, and suprachiasmatic nuclei, and in the lateral preoptic area. All of the other hypothalamic nuclei investigated exhibited moderate levels of the peptide with lowest concentrations in mammilary body, medial forebrain bundle (preoptic), and supraoptic nucleus.

Mesencephalon (Table IV). The substantia nigra and the periaqueductal gray (SGC) have the highest concentrations of $\beta$-neo-endorphin in the midbrain (312.9 and $288.6 \mathrm{fmol} / \mathrm{mg}$ of protein, respectively). Cell groups surrounding the substantia nigra (red nucleus, ventral tegmental area, and interpeduncular nucleus) have much lower levels than does the substantia nigra itself. The rest of the mesencephalic nuclei, except the inferior colliculus which is poor in the peptide, contain moderate amounts of the peptide.

Pons (Table V). In general, the tegmentum (parabrachial nuclei, nucleus locus ceruleus, and tegmental nuclei) is richer in $\beta$-neo-endorphin than is the basal pons (pontine nuclei, pontine reticular nuclei, and superior olive). The parabrachial nuceli are among the richest nuclei in the brain.

Cerebellum (Table V). Both the cerebellar cortex (samples from the vermis and hemispheres and cerebellar nuclei (all three nuclei were pooled) contain low levels of $\beta$-neo-endorphin.

TABLE II

ir- $\beta$-Neo-endorphin concentrations in the diencephalic (except hypothalamic) nuclei of the rat

\begin{tabular}{|c|c|c|c|}
\hline & Regions & $\begin{array}{l}\text { ir- } \beta \text {-Neo-endorphin } \\
\text { Concentrations } \\
(\text { mean } \pm \text { SEM) }\end{array}$ & $\begin{array}{r}\text { Molar Ratio } \\
(\alpha \text {-neo: } \beta \text {-neo })\end{array}$ \\
\hline & & $\mathrm{fmol} / \mathrm{mg}$ of protein & \\
\hline 26 & $\begin{array}{l}\text { Anterior ventral thalamic } \\
\text { nucleus }\end{array}$ & $112.6 \pm 17.6(5)^{a}$ & 0.5 \\
\hline 27 & $\begin{array}{l}\text { Periventricular thalamic } \\
\text { nucleus }\end{array}$ & $166.3 \pm 13.1(6)$ & 1.4 \\
\hline 28 & Ventral thalamic nucleus & $92.1 \pm 12.7(5)$ & 1.0 \\
\hline 29 & Medial thalamic nucleus & $110.6 \pm 11.0(5)$ & 0.6 \\
\hline 30 & Nucleus reuniens & $176.1 \pm 19.6(5)$ & 0.7 \\
\hline 31 & Rhomboid nucleus & $112.9 \pm 21.2(6)$ & 1.0 \\
\hline 32 & Lateral thalamic nucleus & $114.0 \pm 27.4(5)$ & 0.5 \\
\hline 33 & Parafascicular nucleus & $118.6 \pm 10.0(5)$ & 1.2 \\
\hline 34 & Posterior thalamic nucleus & $122.5 \pm 16.2(6)$ & 0.5 \\
\hline 35 & Lateral geniculate body & $140.7 \pm 37.6(5)$ & 0.5 \\
\hline 36 & Medial geniculate body & $116.1 \pm 22.5$ & 0.9 \\
\hline 37 & $\begin{array}{l}\text { Habenular nuclei (med. } \\
\text { \& lat.) }\end{array}$ & $133.9 \pm 13.8(4)$ & 0.6 \\
\hline 38 & Zona incerta & $155.9 \pm 23.5(6)$ & 2.3 \\
\hline
\end{tabular}

${ }^{a}$ Numbers in parentheses, number of samples.
TABLE III

ir- $\beta$-Neo-endorphin content in nuclei of the hypothalamus

\begin{tabular}{|c|c|c|c|}
\hline & Regions & $\begin{array}{l}\text { ir- } \beta \text {-Neo-endorphin } \\
\text { Concentrations } \\
(\text { mean } \pm \text { SEM })\end{array}$ & $\begin{array}{l}\text { Molar Ratio } \\
(\alpha-\text { neo: } \beta \text {-neo })\end{array}$ \\
\hline & & $\mathrm{fmol} / \mathrm{mg}$ of protein & \\
\hline 39 & Medial preoptic nucleus & $217.2 \pm 31.3(5)^{a}$ & 1.7 \\
\hline 40 & Lateral preoptic area & $278.8 \pm 49.4(6)$ & 3.6 \\
\hline 41 & $\begin{array}{l}\text { Medial forebrain bundle } \\
\text { (preoptic) }\end{array}$ & $161.5 \pm 30.8(5)$ & 2.0 \\
\hline 42 & Periventricular nucleus & $230.6 \pm 21.2(6)$ & 1.8 \\
\hline 43 & Supraoptic nucleus & $176.2 \pm 21.4(6)$ & 1.1 \\
\hline 44 & Paraventricular nucleus & $266.3 \pm 29.9(6)$ & 1.7 \\
\hline 45 & Suprachiasmatic nucleus & $256.2 \pm 30.1(6)$ & 1.6 \\
\hline 46 & $\begin{array}{l}\text { Anterior hypothalamic } \\
\text { nucleus }\end{array}$ & $282.3 \pm 34.9(6)$ & 1.8 \\
\hline 47 & Median eminence & $341.4 \pm 30.7(5)$ & 1.5 \\
\hline 48 & Arcuate nucleus & $276.2 \pm 41.8(6)$ & 1.4 \\
\hline 49 & Ventromedial nucleus & $262.5 \pm 44.9(6)$ & 1.5 \\
\hline 50 & Dorsomedial nucleus & $320.1 \pm 38.4(6)$ & 1.3 \\
\hline 51 & Perifornical nucleus & $249.8 \pm 38.2(6)$ & 0.8 \\
\hline 52 & $\begin{array}{l}\text { Posterior hypothalamic } \\
\text { nucleus }\end{array}$ & $202.2 \pm 24.4(6)$ & 1.2 \\
\hline 53 & $\begin{array}{l}\text { Medial forebrain bundle } \\
\text { (hypothalamic) }\end{array}$ & $204.8 \pm 44.7(5)$ & 1.7 \\
\hline 54 & $\begin{array}{l}\text { Dorsal premammillary } \\
\text { nucleus }\end{array}$ & $248.1 \pm 28.3(6)$ & 1.4 \\
\hline 55 & $\begin{array}{l}\text { Ventral premammillary } \\
\text { nucleus }\end{array}$ & $214.5 \pm 23.2(6)$ & 1.2 \\
\hline 56 & Mammillary body & $125.7 \pm 32.8(6)$ & 1.1 \\
\hline
\end{tabular}

${ }^{a}$ Numbers in parentheses, number of samples.

Medulla oblongata (Table V). A wide range of ir- $\beta$-neoendorphin concentrations was found in the medulla oblongata. The richest area (nucleus of the solitary tract, medial part) contains 4.6 times as much peptide as the poorest (cochlear nuclei). The prepositus hypoglossal nucleus also contains a high level of the peptide. The remainder of medullary nuclei investigated exhibit moderate concentrations of the peptide (with the exception of the motor facial nucleus which has a low concentration of the peptide).

Circumventricular organs (Table VI). Moderate concentrations of ir- $\beta$-neo-endorphin were detected in the circumventricular organs. The highest concentration was measured in the subcommissural organ followed by organum vasculosum laminae terminalis. The subfornical organ has a lower ir- $\beta$-neo-endorphin concentration than the other circumventricular organs.

Spinal cord. Low levels of ir- $\beta$-neo-endorphin were measured in the cervical, thoracic, and lumbar segments of the spinal cord (Table VII).

Pituitary gland. The neurointermediate lobe of the pituitary gland contains very high levels of $\beta$-neo-endorphin $(9407.3 \mathrm{fmol} / \mathrm{mg}$ of protein) (Table VIII).

\section{Discussion}

Using a sensitive and specific RIA, we have studied the distribution of the opioid peptide, $\beta$-neo-endorphin, in discrete areas of the rat brain, in the spinal cord, and in the neurointermediate lobe of the pituitary gland. Our data show (1) that ir- $\beta$-neo-endorphin is present at all levels of the neuraxis, (2) that it is unevenly distributed, 
TABLE IV

$i r-\beta$-Neo-endorphin content in the mesencephalon and pons

\begin{tabular}{|c|c|c|c|}
\hline & Regions & $\begin{array}{c}\text { ir- } \beta \text {-Neo-endorphin } \\
\text { Concentrations } \\
\text { (mean } \pm \text { SEM) } \\
\end{array}$ & $\begin{array}{l}\text { Molar Ratio } \\
(\alpha \text {-neo: } \beta \beta \text {-neo })\end{array}$ \\
\hline & & $\mathrm{fmol} / \mathrm{mg}$ of protein & \\
\hline 57 & Substantia nigra & $312.9 \pm 47.1(6)^{\alpha}$ & 5.4 \\
\hline 58 & Ventral tegmental area & $133.5 \pm 26.7(6)$ & 1.2 \\
\hline 59 & Interpeduncular nucleus & $110.3 \pm 24.1(6)$ & 1.2 \\
\hline 60 & Red nucleus & $152.2 \pm 21.6(5)$ & 0.5 \\
\hline 63 & Periaqueductal gray matter (SGC) & $288.6 \pm 30.5(6)$ & 1.5 \\
\hline 64 & Dorsal raphe nucleus & $154.6 \pm 19.7(6)$ & 1.6 \\
\hline 65 & Nucleus cuneiformis (ret. form.) & $119.4 \pm 17.6(5)$ & 1.4 \\
\hline \multicolumn{4}{|l|}{ Pons } \\
\hline 66 & Locus ceruleus & $170.5 \pm 22.7(6)$ & 1.8 \\
\hline 72 & Motor trigeminal nucleus & $107.4 \pm 23.5(5)$ & 1.0 \\
\hline 73 & Sensory trigeminal nucleus & $143.5 \pm 19.0(6)$ & 1.5 \\
\hline
\end{tabular}

${ }^{a}$ Numbers in parentheses, number of samples.

TABLE V

ir- $\beta$-Neo-endorphin concentrations in medulla oblongata and cerebellum

\begin{tabular}{|c|c|c|c|}
\hline & Regions & $\begin{array}{l}\text { ir- } \beta \text {-Neo-endorphin } \\
\text { Concentrations } \\
(\text { mean } \pm \text { SEM) }\end{array}$ & $\begin{array}{l}\text { Molar Ratio } \\
\alpha \text {-neo: } \beta \text {-neo) }\end{array}$ \\
\hline \multicolumn{4}{|c|}{$\begin{array}{l}\mathrm{fmol} / \mathrm{mg} \text { of } \\
\text { protein }\end{array}$} \\
\hline \multicolumn{4}{|c|}{ Medulla oblongata } \\
\hline 74 & Nucl. tract. spin. Vth & $107.8 \pm 16.6(6)^{a}$ & 0.9 \\
\hline 75 & Gracilis nucleus & $118.9 \pm 20.4(5)$ & 1.1 \\
\hline 76 & Cuneate nucleus & $139.4 \pm 17.1(6)$ & 1.3 \\
\hline 77 & $\begin{array}{l}\text { Medullary reticular nuclei } \\
\text { (vent. \& dors.) }\end{array}$ & $117.2 \pm 16.6(4)$ & 1.3 \\
\hline 78 & $\begin{array}{l}\text { Paramedian reticular nu- } \\
\text { cleus }\end{array}$ & $118.9 \pm 23.5(5)$ & 0.7 \\
\hline 79 & $\begin{array}{l}\text { Nucleus of solitary tract } \\
\text { (NTS) (medial) }\end{array}$ & $278.5 \pm 60.8(6)$ & 1.6 \\
\hline 80 & NTS (commissural part) & $228.1 \pm 23.4(6)$ & 1.7 \\
\hline 81 & $\begin{array}{l}\text { Motor hypoglossal nu- } \\
\text { cleus }\end{array}$ & $185.5 \pm 26.0(5)$ & 1.3 \\
\hline 82 & $\begin{array}{l}\text { Prepositus hypoglossal } \\
\text { nucleus }\end{array}$ & $252.9 \pm 31.8(6)$ & 1.6 \\
\hline 83 & Nucleus ambiguus & $164.6 \pm 21.5(6)$ & 1.7 \\
\hline 84 & Lateral reticular nucleus & $137.0 \pm 10.4(5)$ & 1.1 \\
\hline 85 & $\begin{array}{l}\text { Cochlear nuclei (dors. \& } \\
\text { vent.) }\end{array}$ & $59.0 \pm 13.0(6)$ & 1.1 \\
\hline 86 & Medial vestibular nucleus & $128.7 \pm 19.5(5)$ & 0.6 \\
\hline 87 & Lateral vestibular nucleus & $116.8 \pm 13.8(5)$ & 0.6 \\
\hline 88 & Inferior olive & $102.2 \pm 15.7(6)$ & 1.3 \\
\hline 89 & Nucleus raphe magnus & $114.0 \pm 19.1(6)$ & 1.2 \\
\hline 90 & Motor facial nucleus & $97.3 \pm 18.0(5)$ & 0.9 \\
\hline 91 & $\begin{array}{l}\text { Gigantocellular reticular } \\
\text { nucleus }\end{array}$ & $125.7 \pm 14.3(4)$ & 0.7 \\
\hline 92 & $\begin{array}{l}\text { Parvicellular reticular nu- } \\
\text { cleus }\end{array}$ & $143.2 \pm 18.6(6)$ & 1.6 \\
\hline \multicolumn{4}{|c|}{ Cerebellum } \\
\hline 93 & Cortex & $82.2 \pm 13.5(5)$ & 0.5 \\
\hline 94 & Nuclei & $90.1 \pm 17.5(5)$ & 0.5 \\
\hline
\end{tabular}

${ }^{a}$ Numbers in parentheses, number of samples.
TABLE VI

Concentrations of ir- $\beta$-neo-endorphin in the circumventricular organs

\begin{tabular}{|c|c|c|c|}
\hline & Regions & $\begin{array}{l}\text { ir- } \beta \text {-Neo-endorphin } \\
\text { Concentrations } \\
\text { (mean } \pm \text { SEM) }\end{array}$ & $\begin{array}{l}\text { Molar Ratio } \\
\alpha \text {-neo: } \beta \text {-neo) }\end{array}$ \\
\hline \multicolumn{4}{|c|}{$\begin{array}{c}\mathrm{fmol} / \mathrm{mg} \text { of } \\
\text { protein }\end{array}$} \\
\hline 95 & $\begin{array}{l}\text { Organum vasculosum laminae } \\
\text { terminalis }\end{array}$ & $202.4 \pm 31.1(6)^{a}$ & 0.8 \\
\hline 96 & Subfornical organ & $108.1 \pm 19.8(5)$ & 0.7 \\
\hline 97 & Subcommissural organ & $205.0 \pm 28.1(5)$ & 1.1 \\
\hline 98 & Area postrema & $190.7 \pm 20.7(5)$ & 1.0 \\
\hline
\end{tabular}

${ }^{a}$ Numbers in parentheses, number of samples.

and (3) that the ratio of $\alpha$-neo-endorphin to $\beta$-neoendorphin in different brain areas is variable.

Our results are in good agreement with reports describing the distribution of ir- $\beta$-neo-endorphin in gross anatomical brain regions (Kitamura et al., 1982; Weber et al., 1982a). No immunohistochemical data on the distribution of $\beta$-neo-endorphin in the rat central nervous system have been published to date, but it seems that areas with high concentrations of ir- $\beta$-neo-endorphin contain large numbers of ir- $\alpha$-neo-endorphin fibers and terminals. Thus, the most dense $\alpha$-neo-endorphin-positive fiber systems were found in the median eminence and substantia nigra, which contain substantial amounts of ir- $\beta$-neo-endorphin. Significant amounts of $\beta$-neoendorphin were also found in areas containing $\alpha$-neoendorphin-positive cell bodies such as the dorsomedial, anterior hypothalamic, paraventricular, and parabrachial nuclei, central gray, and nucleus of the solitary tract. All of the above-mentioned nuceli also contain $\alpha$ neo-endorphin-positive nerve fibers and/or terminals.

The abundance of $\beta$-neo-endorphin in median eminence (the richest brain area investigated), in several hypothalamic nuclei, and in the posterior pituitary suggests a role for this peptide in neuroendocrine regulation. 
TABLE VII

Distribution of ir- $\beta$-neo-endorphin in the spinal cord

\begin{tabular}{lcc}
\hline \multicolumn{1}{c}{ Areas } & $\begin{array}{c}\text { ir- } \beta \text {-Neo-endorphin } \\
\text { Concentrations } \\
\text { (mean } \pm \text { SEM) }\end{array}$ & $\begin{array}{c}\text { Molar Ratio } \\
(\alpha \text {-neo: } \beta \text { - } \\
\text { neo) }\end{array}$ \\
\hline Cervical spinal cord & $84.0 \pm 7.8(6)^{a}$ & 1.6 \\
Thoracic spinal cord & $50.2 \pm 9.8(5)$ & 1.7 \\
Lumbar spinal cord & $39.2 \pm 9.6(6)$ & 1.5 \\
\hline
\end{tabular}

${ }^{a}$ Numbers in parentheses, number of samples.

TABLE VIII

ir- $\beta$-Neo-endorphin content in the neurointermediate lobe of the pituitary gland

\begin{tabular}{ccc}
\hline Lobe & $\begin{array}{c}\text { ir- } \beta \text {-Neo-endorphin } \\
\text { Concentration } \\
\text { (mean } \pm \text { SEM) }\end{array}$ & $\begin{array}{c}\text { Molar Ratio } \\
(\alpha \text {-neo: } \beta \text {-neo })\end{array}$ \\
\hline Nmol/mg of \\
protein \\
Neurointermediate & $9407.3 \pm 776.6(18)$ & 1.1 \\
\hline
\end{tabular}

As mentioned earlier, $\alpha$-neo-endorphin and $\beta$-neo-endorphin are derived from a larger precursor molecule. They are separated from dynorphin A and dynorphin B by two basic amino acids - lysine and arginine (Kakidani et al., 1982). It appears that, when the precursor is processed proteolytically, it is cleaved either (1) between the lysine and arginine or (2) on the carboxy terminal side of the Arg, and then the Arg is efficiently removed, generating $\alpha$-neo-endorphin. The $\mathrm{C}$-terminal lysine of $\alpha$ neo-endorphin could, in principle, be trimmed off by a carboxypeptidase B-like enzyme (one that removes basic residues from a peptide's C-terminus) or by a postproline cleaving enzyme. Both enzyme activities have been demonstraed in brain homogenates (Hersh and McKelvy, 1979; Docherty et al., 1982), but the fact that removal of basic residues by pancreatic carboxypeptidase $\mathrm{B}$ is inhibited by adjacent prolyl residues (Folk and Gladner, 1958) suggests that a post-proline cleaving enzyme may be the better candidate.

Our data show that the molar ratio of $\alpha$-neo-endorphin to $\beta$-neo-endorphin is inconstant; in two-thirds of brain regions $\alpha$-neo-endorphin predominates, suggesting that the trimming enzyme, no matter what its type, does not remove $\alpha$-neo-endorphin's C-terminal lysine readily. Surprisingly, though, in about one-third of the brain areas examined, $\beta$-neo-endorphin concentrations were greater than those of $\alpha$-neo-endorphin. The physiological importance of $\alpha$-neo-endorphin versus $\beta$-neo-endorphin remains to be determined.

\section{References}

Docherty, K., and D. F. Steiner (1982) Post-translational proteolysis in polypeptide hormone biosynthesis. Annu. Rev. Physiol. 44: 625-638.
Fischli, W., A. Goldstein, M. W. Hunkapiller, and L. E. Hood (1982) Isolation and amino acid sequence analysis of a 4000 dalton dynorphin from porcine pituitary. Proc. Natl. Acad. Sci. U. S. A. 79: 5435-5437.

Folk, J. E., and J. A. Gladner (1958) Carboxypeptidase B. I. purification of the zymogen and specificity of the enzyme. J. Biol. Chem. 231: 379-391.

Goldstein, A., W. Fischli, L. I. Lowney, M. Hunkapiller, and L. Hood (1981) Porcine pituitary dynorphin: Complete amino acid sequence of the biologically active heptadecapeptide. Proc. Natl. Acad. Sci. U. S. A. 78: 7219-7223.

Hersh, L. P., and J. F. McKelvy (1979) Enzymes involved in the degradation of thyrotropin releasing hormone (TRH) and luteinizing hormone releasing hormone ( $\mathrm{I} . \mathrm{H}-\mathrm{RH})$ in bovine brain. Brain Res. 168: $553-564$.

Hunter, W. M., and F. C. Greenwood (1962) Preparation of iodine-131 labeled human growth hormone of high specific activity. Nature 194: 495-496.

Kakidani, H., Y. Furutani, H. Takahashi, M. Noda, Y. Morimoto, T. Hirose, M. Asai, S. Inayama, S. Nakanishi, and S. Numa (1982) Cloning and sequence analysis of cDNA for porcine $\beta$-neo-endorphin/dynorphin precursor. Nature 298: $245-249$.

Kangawa, K., N. Minamino, N. Chino, S. Sakakibara, and H. Matsuo (1981) The complete amino acid sequence of $\alpha$-neoendorphin. Biochem. Biophys. Res. Commun. 99: 871-888.

Kilpatrick, D. L., A. Wahlstrom, H. W. Lahm, R. W. Blacher, E. Ezra, G. Fleminger, and S. Udenfriend (1982) Characterization of rimorphin, a new (leu) enkephalin-containing peptide from bovine posterior pituitary glands. Life Sci. 31: 18491852.

Kitamura, K., N. Minamino, Y. Hayashi, K. Kangawa, and H. Matsuo (1982) Regional distribution of $\beta$-neo-endorphin in rat brain and pituitary. Biochem. Biophys. Res. Commun. 109: 966-974.

Lowry, O. H., N. J. Rosebrough, A. L. Farr, and R. J. Randall (1951) Protein measurement with the Folin phenol reagent. J. Biol. Chem. 193: 265-275.

Minamino, N., K. Kangawa, N. Chino, S. Sakakibara, and H. Matsuo (1981) $\beta$-Neo-endorphin, a new hypothalamic "big" Leu-enkephalin of porcine origin: Its purification and the complete amino acid sequence. Biochem. Biophys. Res. Commun. 99: 864-870.

Oka, T., K. Negishi, M. Kajiwara, Y. Watanabe, Y. Ishizuka, and T. Matsumiya (1982) The choice of opiate receptor subtype by neo-endorphins. Eur. J. Pharmacol. 79: 301-305.

Palkovits, M. (1973) Isolated removal of hypothalamic or other brain nuclei of the rat. Brain Res. 59: 449-450.

Weber, E., C. J. Evans, J. K. Chang, and J. D. Barchas (1982a) Brain distributions of $\alpha$-neo-endorphin and $\beta$-neo-endorphin: Evidence for regional processing differences. Biochem. Biophys. Res. Commun. 108: 81-88.

Weber, E., K. A. Roth, and J. D. Barchas (1982b) Immunohistochemical distribution of $\alpha$-neo-endorphin/dynorphin neuronal systems in rat brain: Evidence for colocalization. Proc. Natl. Acad. Sci. U. S. A. 79: 3062-3066.

Zamir, N., M. Palkovits, and M. J. Brownstein (1984) The distribution of immunoreactive $\alpha$-neo-endorphin in the central nervous system of the rat. J. Neurosci. 4: 1240-1247. 